UDK 929 Zrinski, obitelj 929 Evlija Čelebija 94(497.5)"17"(093) Primljeno: 20. 1. 2017. Prihvaćeno: 1. 6. 2017. Izvorni znanstveni rad DOI: $10.22586 /$ pp.v52i0.8

\title{
Obitelj Zrinski u Putopisu Evlije Čelebija i usporedba s neosmanskim izvorima
}

\author{
Anđelko Vlašić \\ Hrvatski institut za povijest \\ Podružnica za povijest Slavonije, Baranje i Srijema \\ Ante Starčevića 8 \\ 35000 Slavonski Brod \\ Republika Hrvatska \\ E-adresa: andelko.vlasic@gmail.com
}

U radu se iznose novi pogledi na povijest obitelji Zrinski na temelju Putopisa osmanskoga putopisca Evlije Čelebija. Domaći istraživači povijesti Zrinskih koristili su Putopis u prijevodu bosansko-hercegovačkoga orijentalista Hazima Šabanovića, a nedavno izdanje autografa, odnosno izvornoga rukopisnog primjerka Putopisa, pruža nam mogućnost provjere podataka iz Šabanovićeva izdanja i iznošenje nekih dosad nepoznatih podataka o djelovanju Nikole VII. Zrinskog od 1660. do 1664., o izgledu i funkcioniranju dvorca Zrinskih u Čakovcu, o stanju u Međimurju s obzirom na ratno djelovanje osmanskih odreda, o šumskim područjima na habsburško-osmanskoj granici u tadašnjoj Slavoniji, o opsadi utvrde Novi Zrin 1664. godine i općenito o osmansko-hrvatskim odnosima u spomenutome razdoblju. Novi podaci uspoređuju se s dosad poznatim izvorima i literaturom o obitelji Zrinski u drugoj polovici 17. stoljeća i donose se novi zaključci iz osmanskoga kuta gledanja, koji nam pruža Evlija Čelebi.

Ključne riječi: obitelj Zrinski, Evlija Čelebi, Međimurje, Slavonija, Novi Zrin, šume, osmansko-hrvatski odnosi 
Evlija Čelebi ${ }^{1}$ (Evliyâ Çelebi, 1611. - 1687. ili kasnije²) proslavljeni je osmanski putopisac i diplomat koji je u razdoblju od 1640. do 1680-ih godina kao pratitelj osmanskih velikodostojnika putovao diljem Osmanskoga Carstva i susjednih zemalja. Svoja je putovanja opisao u djelu Seyâhatnâme (Putopis) u kojemu je iznio povijesne, zemljopisne i etnografske značajke proputovanih krajeva, među ostalim i hrvatskih zemalja, kroz koje je u nekoliko navrata prošao od 1660. do 1664. godine. ${ }^{3}$ Hrvatska javnost upoznala se s Putopisom preko prijevoda bosansko-hercegovačkoga orijentalista Hazima Šabanovića, koji je 1954. i 1957. objavio prijevod dijelova Putopisa o jugoslavenskim zemljama. ${ }^{4}$ Dosad je velik broj domaćih istraživača koristio podatke iz toga prijevoda Putopisa za radove o povijesti obitelji Zrinski. ${ }^{5}$ Iako su dotični autori potvrđivali važnost Evlijinih podataka, uglavnom su tek citirali poveće pasuse putopisa ne ulazeći u njihovu dublju analizu i ograđivali su se od "pretjerivanja" i "bombastičnih" iskaza "neuvjerljivoga" putopisca. Šabanovićev prijevod Putopisa temeljio se na dijelovima dotad jedine poznate verzije Evlijina djela, koji su objavljeni u razdoblju od 1896. do 1938. u Istanbulu i iz koje se izdavači nisu libili izostaviti dijelove koji su im se činili neprikladnima iz različitih razloga. U međuvremenu je pronađeno još nekoliko rukopisnih verzija Putopisa, od kojih se za onu pronađenu u muzeju Topkapı u

1 Ovaj članak nastao je u sklopu projekta IP-2014-09-6719, Od prašuma do oranica: povijest antropizacije šuma u Slavoniji od srednjeg vijeka do početka 20. stoljeća, koji financira Hrvatska zaklada za znanost. Budući da nije poznato drugo Evlijino ime osim osobnoga i da je "čelebi" osmanska titula približnoga značenja "gospodin," u radu će se prilikom oslovljavanja koristiti putopiščevo osobno ime.

2 Nuran Tezcan, "When did Evliya Çelebi die?", u: Evliyâ Çelebi. Studies and Essays Commemorating the 400th Anniversary of his Birth, ur. Nuran Tezcan, Semih Tezcan, Robert Dankoff (Istanbul: Republic of Turkey, Ministry of Culture and Tourism Publications, 2012), 30-32.

3 Za više podataka o Evliji Čelebiju pogledati: Robert Dankoff, An Ottoman Mentality. The World of Evliya Çelebi (Leiden; Boston: Brill, 2006), 9-32.

${ }_{4}$ Evlija Čelebi, Putopis. Odlomci o jugoslovenskim zemljama, preveo Hazim Šabanović (Sarajevo: Svjetlost, 1967).

${ }^{5}$ Hrvoje Petrić, Dragutin Feletar, Petar Feletar, Novi Zrin. Zrinska utvrda na Muri (1661-1664) (Donja Dubrava; Zagreb: Hrvatski zemljopis; Naklada dr. Feletar, 2001), 7, 16, 30, 80, 86, 88-89; Dragutin Feletar, Hrvoje Petrić, "Die Festung Novi Zrin im Europäischen kontext (1661-1664)", Podravina: časopis za multidisciplinarna istraživanja 1 (2002): 101-102; Nenad Moačanin, "Pristup ekohistoriji Podravine prema osmanskim izvorima”, Ekonomska i ekohistorija 1 (2005): 140-143; Vladimir Kalšan, Međimurska povijest (Zagreb: Vladimir Kalšan, 2006), 103-104; Hrvoje Petrić, "Ljudi i selo Donja Dubrava na Dravi do sredine 20. stoljeća”, u: Općina i župa Donja Dubrava: povijesno-geografska monografija, ur. Dragutin Feletar et al. (Samobor: Meridijani, 2007), 80; Dragutin Feletar, "Legradska kapetanija u obrani od Osmanlija s posebnim osvrtom na Novi Zrin", Rad Hrvatske akademije znanosti i umjetnosti. Razred za društvene znanosti 1 (2011): 60-61, 66-67, 74; Dragutin Feletar, "Zrinski Legrad i njegova uloga u obrani od Osmanlija”, u: Politička, kulturna i društvena djelatnost Zrinskih i Frankopana u Hrvatskoj, ur. Juraj Kolarić (Čakovec: Zrinska garda Čakovec, 2011), 177, 182; Dragutin Feletar, “Značenje zrinskog Legrada i Novoga Zrina u obrani od Osmanlija”, u: Susreti dviju kultura. Obitelj Zrinski u hrvatskoj i mađarskoj povijesti, ur. Romana Horvat (Zagreb: Matica hrvatska, 2012), 171, 176, 182; Gábor Hausner, Lajos Négyesi, József Padányi, "Novi Zrin u svjetlu izvora i istraživanja terena", u: Susreti dviju kultura. Obitelj Zrinski u hrvatskoj i mađarskoj povijesti, ur. Romana Horvat (Zagreb: Matica hrvatska, 2012), 202; Vladimir Kalšan, Nikola Zrinski Čakovečki (1620.-1664.) (Čakovec: Muzej Međimurja Čakovec, 2014), 16, 23. 
Istanbulu smatra da se radi o autografu, odnosno izvornome rukopisnom primjerku. Ta je verzija objavljena između 1998. i 2007. na izvornome osmanskom turskom jeziku i transliterirana na latinicu. ${ }^{6}$ Posvuda $u$ autografu, a ponajviše $u$ petom, šestom i sedmom svesku, nalaze se dosad neobrađeni dijelovi koji govore o hrvatskim krajevima i kojih zbog spomenutih izostavljanja nema u Šabanovićevu prijevodu. ${ }^{7}$ Većinom se radi o manjim ulomcima, rečenicama ili dijelovima rečenica, ali zbog iznimne važnosti Evlijinih komentara neki od tih dijelova vrlo su bitni za hrvatsku povijest. Ocjene Evlijina djela sežu od onih da je njegov putopis izniman izvor za proučavanje povijesti druge polovice 17. stoljeća do onih da je Putopis tek zbirka izmišljenih i poluizmišljenih priča i pretjerivanja. Revalorizacija Evlijina djela, koju su svjetski osmanisti proveli u zadnjih dvadesetak godina, pokazala je da je ono uistinu nezamjenjiv i općenito vrlo pouzdan izvor za povijest Osmanskoga Carstva, a time i hrvatskih zemalja pod osmanskom vlašću. ${ }^{8} \mathrm{Na}$ postojanje dosad nepoznatih podataka o povijesti obitelji Zrinski u Putopisu prvi su upozorili Kornelija Jurin Starčević i Nenad Moačanin. ${ }^{9}$

Sve navedeno upućuje na zaključak da bi za proširenje spoznaja o obitelji Zrinski u drugoj polovici 17. stoljeća i o svekolikom kontekstu onovremene hrvatske povijesti bilo korisno provjeriti i potvrditi Šabanovićev prijevod usporedbom s autografom, s neosmanskim izvorima i relevantnom literaturom o obitelji Zrinski u drugoj polovici 17. stoljeća. Pored toga, u radu će se iznijeti nekoliko novih podataka iz autografa i korelirati ih s dosadašnjim spoznajama o Zrinskima. Svi citati iz Putopisa bit će preuzeti iz Šabanovićeva prijevoda ako se za iste ne može ponuditi dorađeniji, točniji prijevod; u tom će slučaju autor članka ponuditi svoj prijevod, kao i za ulomke koji su nedostajali u Šabanovićevu prijevodu i nalaze se jedino u autografu. Potonji ulomci bit će podvučeni kako bi se lakše razlikovali od dosad poznatih podataka.

U vrijeme Evlijina posjeta Međimurju obitelj Zrinski već je bila izrasla u najmoćniju hrvatsku plemićku obitelj i posjedovala je imanja diljem tadašnje Hrvatske, Slavonije i jugozapadne Ugarske, s Međimurjem i Čakovcem kao središtem obiteljske vlasti. Hrvatski i slavonski ban Nikola VII. Zrinski (1647. - 1664.) stolovao je u obiteljskome dvorcu u Čakovcu od 1637. godine i bio je predstavnik

\footnotetext{
${ }^{6}$ Nenad Moačanin, Kornelija Jurin Starčević, “Novi' Evlija Čelebi: autograf 'Putopisa”, Književna smotra 173 (2014): 79-81.

7 Evliyâ Çelebi bin Derviş Mehemmed Zillî, Evliyâ Çelebi Seyahatnâmesi Topkapı Sarayı Kütüphanesi Bağdat 307 Numaralı Yazmanın Transkripsiyonu - Dizini (prir. Yücel Dağlı, Seyit Ali Kahraman, İbrahim Sezgin), sv. V (Istanbul: Yapı Kredi Yayınları, 2001); Isti, Evliyâ Çelebi Seyahatnâmesi Topkapı Sarayı Kütüphanesi Revan 1457 Numaralı Yazmanın Transkripsiyonu - Dizini (prir. Seyit Ali Kahraman, Yücel Dağl1), sv. VI. (Istanbul: Yapı Kredi Yayınları, 2002); Isti, Evliyâ Çelebi Seyahatnâmesi Topkapı Sarayı Kütüphanesi Bağdat 308 Numaralı Yazmanın Transkripsiyonu - Dizini, prir. Yücel Dağlı, Seyit Ali Kahraman, Robert Dankoff, sv. VII (Istanbul: Yapı Kredi Yayınları, 2003).

8 Moačanin, Starčević, “'Novi' Evlija”, 78-79; Dankoff, An Ottoman Mentality, XV-XVI, 153.

9 Moačanin, Jurin Starčević, “'Novi' Evlija”, 88.
} 
četvrte generacije obitelji koja je imala premoćnu važnost u otporu osmanskome osvajanju hrvatskih zemalja. Često se sukobljavao s Osmanlijama na bojnome polju, napadao njihova vojna uporišta u Slavoniji i uništavao osmansku logistiku. ${ }^{10}$ Nizozemski učenjak i putopisac Jacobus Tollius u jednome je pismu opisao svoj posjet Nikoli VII. u Čakovcu u lipnju 1660. i zabilježio da su Nikoline "česte i uspješne provale u područje turske vlasti zavrijedile to da glas o njima ispuni čitav kršćanski svijet, a da Turcima i samo ime Zrinsko bude na užas." ${ }^{11}$ Evlijin opis Nikole VII. slaže se s Tolliusovim komentarom u tome da pokazuje važnost koju su obitelj Zrinski i osobito Nikola VII. imali u očima Osmanlija, o čemu će kasnije biti više riječi.

U rujnu 1656. habsburško-hrvatske snage pod vodstvom kneza Jurja IV. Frankopana Tržačkog kod Križanić-Turnja porazile su osmansku vojsku pod zapovjedništvom požžškoga sandžakbega Sarhoşzade Ibrahim-paše Memibegovića i bihaćkoga kapetana Mustaj-bega Hasumovića. Potonji je bio zarobljen i izgleda da je završio u zarobljeništvu kod Nikole VII. Zrinskog jer Evlija u svojem putopisu kaže da je u studenome 1660. došla sultanska zapovijed iz Istanbula od velikog vezira Köprülü Mehmed-paše (Ćuprilića) upućena bosanskome beglerbegu Melek Ahmed-paši da otkupi Mustaj-bega iz zarobljeništva, za što je Melek Ahmedpaša odredio Evliju. ${ }^{12}$ U Putopisu Evlija opisuje bitku kod Križanić-Turnja, ali taj dio Evlijina pripovijedanja baca sjenu sumnje na njegove tvrdnje jer u usta Nikole VII. Zrinskoga stavlja opis spomenute bitke: Zrinski je Evliji navodno ispričao da je u toj bitci poginulo $\underline{8060}^{13}$ kršćanskih i 40 osmanskih vojnika, od kojih je još 70 bilo zarobljeno. Cjelokupni Evlijin opis te bitke i navedene brojke zvuče neuvjerljivo jer je Mustaj-beg navodno osobno ubio pet "kapetana" Nikole VII., za koga Evlija implicira da je bio ondje prisutan, a poznato je da Zrinski uopće nije sudjelovao u toj bitci. ${ }^{14}$ Mora se uzeti u obzir da je putopisac neke svoje opise težio prikazati dramatičnijima i time zabaviti svoje čitatelje. ${ }^{15}$

Evlija ni na jednom mjestu u Putopisu ne spominje Mustaj-bega Hasumovića po imenu, nego ga jedino naziva "bihaćkim kapetanom." Međutim, on je bio jedini bihaćki kapetan za kojega se zna da je završio u hrvatskome zarobljeništvu.

\footnotetext{
${ }^{10}$ Petrić, Feletar, Feletar, Novi Zrin, 75; Kalšan, Nikola Zrinski, 6.

${ }^{11}$ Bruna Kuntić-Makvić (prijevod), "Šesto putno pismo Jakova Tolla Preplemenitome i presvijetlome gospodinu Nikoli Witsenu. Gradačko putovanje i gostoprimstvo Zrinskih", u: Zrinski i Europa, ur. Jadranka Damjanov (Zagreb: Društvo mađarskih znanstvenika i umjetnika u Hrvatskoj, 2000), 153; Kalšan, Nikola Zrinski, 15.

${ }^{12}$ Evlija Čelebi, Putopis, 31-32, 173; Evliyâ Çelebi, Evliyâ Çelebi, sv. V, 240-242.

${ }^{13}$ Kod Šabanovića stoji 8030, a pogreška se vjerojatno nalazila već u izdanju koje je Šabanoviću poslužilo kao predložak prilikom prevođenja. Inače, Evlija u putopisu često koristi broj $1060 \mathrm{i}$ druge brojeve čije posljednje dvije znamenke čine 6 i $0(60,160,260 \ldots)$. Zbog toga se može pretpostaviti da je spomenuti broj u tekstu vjerojatno izmišljen. Više o tome: Dankoff, An Ottoman Mentality, 154-156.

${ }^{14}$ Evliyâ Çelebi, Evliyâ Çelebi, sv. V, 275; Evlija Čelebi, Putopis, 247; Radoslav Lopašić, "Spomenici Tržačkih Frankopana", Starine 25 (1892): 201-332.

${ }^{15}$ Moačanin, Jurin Starčević, “'Novi' Evlija”, 86.
} 
Evlija opisuje kako je iz Bihaća poslano dvanaest srijemskih kola blaga za otkup Mustaj-bega iz zarobljeništva ${ }^{16}$ i da je s kolima i pratnjom od dvjesta osmanskih vojnika preko Voćina putovao u osmansku utvrdu Viroviticu, za koju kaže da poslije nje nije bilo nijedne druge "muslimanske utvrde" prema zapadu. ${ }^{17}$ Odande je s pratnjom krenuo na područje pod kontrolom Zrinskih, koje naziva "vilajet [tj. pokrajina] Zrinskog" i koje se pruža zapadno od Virovitice. ${ }^{18}$ Braća Nikola i Petar Zrinski podijelili su obiteljska imanja 1649. godine i Nikola je dobio Međimurje, Vrbovec, Preseku i Rakovec, a Petar je dobio Ozalj, Božjakovinu, Ribnik i posjede u Primorju. ${ }^{19}$ Takva je situacija bila i tijekom Evlijina prolaska kroz hrvatske krajeve. međutim, Evlija za Zagreb, Krapinu, Čazmu i brojne druge hrvatske gradove krivo tvrdi da su to bili gradovi Zrinskih. ${ }^{20}$ Takvo preuveličavanje posjeda Zrinskih ukazuje na važnost koju su Zrinski imali u očima Osmanlija.

Evlija je zapisao da se zapadno od Virovitice nalazilo šumsko područje koje naziva "Krčevina Zrinskih/Zrinskoga" (Zirinoğlu kırıntısı) i izrazima tabur ${ }^{21} \mathrm{i}$ becene, ${ }^{22}$ koji označavaju mjesto zaštićeno opkopom, barikadom, palisadom ili zasjekom, odnosno preprekom načinjenom od posječenih stabala. Krčevina je činila dio habsburško-osmanske granice koja se protezala Poilovljem od Save blago sjeveroistočno prema Dravi između Virovitice i Đurđevca. Evlija spominje da su na prijevojima i strateški važnim mjestima na granici postojali prolazi ili "vrata" kroz zasjeku. ${ }^{23}$ To se područje tijekom habsburško-osmanskih ratova promijenilo od razmjerno dobro naseljene u napuštenu zemlju u kojoj su zbog izostanka redovitoga krčenja šume počele neometano rasti. Evlija navodi da se to područje protezalo na udaljenosti od tri dana hoda od jednoga do drugoga kraja, a put koji je vodio uzduž kroz šumu svake je godine bio obnavljan krčenjem. Evlija ju opisuje kao prašumu "koja se uzdiže do nebesa" jer se nije krčila vjerojatno već stotinu godina. Iz putopiščeva opisa velikoga broja drvosječa koji su krčili tu šumu može se zaključiti da su vjerojatno stotine seljaka svake godine redovito krčile stotine stabala. Nakon krčenja seljaci su slagali drva "na gomile velike kao brda" i to povrh onih stabala koja su bila posječena prethodne godine. Evlija je zapisao da su drvosječe rušili stabla tako golema da su se od jednoga debla mogla izraditi tri čamca. ${ }^{24}$ Nadalje, Evlija opisuje kako je u ono vrijeme rijekom Savom plovilo

\footnotetext{
${ }^{16}$ Srijemska kola su mjera za težinu. Evlija Čelebi, Putopis, 91, 238; Evliyâ Çelebi, Evliyâ Çelebi, sv. V, 271.

${ }^{17}$ Evliyâ Çelebi, Evliyâ Çelebi, sv. V, 272.

${ }^{18}$ Evliyâ Çelebi, Evliyâ Çelebi, sv. V, 269, 271-272; Evlija Čelebi, Putopis, 235, 238-240.

${ }^{19}$ Kalšan, Međimurska povijest, 99; Kalšan, Nikola Zrinski, 11.

${ }^{20}$ Evliyâ Çelebi, Evliyâ Çelebi, sv. VI, 318; Evlija Čelebi, Putopis, 489, 492-493.

${ }^{21}$ Robert Dankoff, Evliya Çelebi Seyahatnamesi Okuma Sözlü̆̆̈̈ (Istanbul: Türk Dilleri Araştırmaları Dizisi, 2004), 254.

${ }^{22}$ Isto, 85.

${ }^{23}$ Evlija Čelebi, Putopis, 241; Evliyâ Çelebi, Evliyâ Çelebi, sv. V, 272.

${ }^{24}$ Evliyâ Çelebi, Evliyâ Çelebi, sv. V, 272; Čelebi, Putopis, 241.
} 
"mnogo tisuća" raznovrsnih plovila izrađenih od stabala oborenih u šumama uz spomenutu granicu u Poilovlju i da se pomoću njih roba za prodaju prevozila nizvodno do Beograda. ${ }^{25}$ Evlija je i druge hrvatske krajeve opisao kao vrlo šumovite; među ostalim je u Podravini prošao kroz tako gustu šumu "da ni sunce nismo vidjeli," a Viroviticu je opisao kao grad smješten u šumi "čija se visoka stabla dižu nebu pod oblake."26

Evlija opisuje kako su se "s unutarnje strane granice Krčevine Zrinskoga"27 nalazile promatračnice raspoređene po brdima na udaljenosti dosega topovskoga hica i da su bile pune vojnika koji bi ispaljivali topovski hitac kao upozorenje u slučaju da se neprijatelj približavao. Tih je kula-promatračnica bilo 367 na Muri, Dravi i Savi, tvrdi Evlija, i svojim pucanjem uzbunjivale bi čitavo spomenuto područje: "Sva se Hrvatska zapali i začas se sakupi čitavo more ljudi." ${ }^{28}$ Toj taktici osmanski su "krajiški gazije"29 doskočili tako što su običavali zapucati iz topova na jednome mjestu, a napasti i pljačkati na drugome. ${ }^{30}$ "Toliko je ta država razvijena i zaštićena, sigurna," tvrdi Evlija, da je čak i sultan Sulejman morao s njima održavati dobre odnose. Zato je "dao krunu" sedmorici "hercega" među ostalima obiteljima Zrinski, Bakanoğlu (Batthyány) i Nadajoğlu (Nádasdy). ${ }^{31}$ Iz navedenoga se može zaključiti da Evlija spominje upravo te obitelji jer su one imale najveće posjede na habsburško-osmanskoj granici i njihovi su članovi bili vrlo aktivni u borbama s Osmanlijama. Inače, na temelju ovoga i kasnijih ulomaka, koji se nalaze jedino u autografu, može se zaključiti da su izdavači rukopisne verzije Putopisa na kojoj se temeljio Šabanovićev prijevod izostavljali (među ostalima) one dijelove teksta koji su sadržavali njima nepoznate antroponime, toponime ili riječi iz njima stranih jezika, u ovome slučaju hrvatskoga.

Evlija nadalje opisuje kako su ga s pratnjom u Krčevinu propustili stražari na "bastionima i kulama" Krčevine nakon što su izjavili da nose otkupninu "kralju Zrinskom." Iz toga se može zaključiti da je otkupljivanje zarobljenika za spomenute stražare bila uobičajena aktivnost na granici. Evlija i pratnja išli su "jedan dan u smjeru sjevera" i stigli u utvrdu Moslavina, što je očita pogreška jer se (današnja Podravska) Moslavina nalazi pedesetak kilometara istočno od Virovitice. Pogreška je možda nastala zbog toga što je Evlija naknadno zapisivao mjesta kroz koja bi prolazio. Ondje ih je poslanik Zrinskoga obavijestio da ih "kralj" poziva da sutradan dođu k njemu. Iz utvrde Moslavina put je trajao dva sata do "kapije

\footnotetext{
${ }^{25}$ Evliyâ Çelebi, Evliyâ Çelebi, sv. V, 272; Moačanin, Jurin Starčević, “'Novi’ Evlija”, 87.

${ }^{26}$ Evliyâ Çelebi, Evliyâ Çelebi, sv. V, 269; sv. VI., 318; Evlija Čelebi, Putopis, 235, 491.

${ }^{27}$ Evliyâ Çelebi, Evliyâ Çelebi, sv. V, 272.

${ }^{28}$ Evliyâ Çelebi, Evliyâ Çelebi, sv. V, Isto, 272; Evlija Čelebi, Putopis, 242.

${ }^{29}$ Gazija (osmanski turski: gazi) islamski vojnik koji se bori protiv nevjernika. Vladimir Anić, Rječnik hrvatskoga jezika (Zagreb: Novi Liber, 1998), 129.

${ }^{30}$ Evliyâ Çelebi, Evliyâ Çelebi, sv. V, 272; Evlija Čelebi, Putopis, 242.

${ }^{31}$ Evliyâ Çelebi, Evliyâ Çelebi, sv. V, 272-273.
} 
na prijevoju," koja je tvorila ulaz u Krčevinu. Ondje je Evlija upozorio pratnju da je s druge strane "neprijateljska zemlja i da su ondje vino i žene dopušteni" te da ih se čuvaju. Prenoćili su u "selu Vaslovin," za koje Nenad Moačanin pretpostavlja da se radi o Varaždinu. ${ }^{32}$ Mjesto se sastojalo od 1000 kuća, čaršije (dijela naselja u kojemu se odvija trgovački i društveni život) i pazara (sajma). Iz toga su mjesta preko spomenutoga glasnika uputili dva istočnjačka ulja ili mirisa, koje je poslala sultanija Kaya, supruga Melek Ahmed-paše, turban izvezen zlatom i pismo s najavom dolaska. Stigla im je vijest da im je Zrinski pripremio "veliku palaču” pored "crkve Zrinskih" u Čakovcu - možda se tu radi o nekoj građevini u blizini pavlinskoga samostana sv. Jelene u današnjemu selu Šenkovec pored Čakovca. Sutradan su "s velikom vojskom" ušli u Čakovec, ili “C̣akatorna na hrvatskom jeziku”, kako navodi Evlija u autografu koristeći mađarski naziv (Csáktornya) za Čakovec. Ponovo su izdavači rukopisne verzije putopisa koju je Šabanović preveo izostavili nepoznati toponim. ${ }^{33}$ Čakovec su zasnovali "ugarski kraljevi” ustvrdio je Evlija, a "stari [ili veliki] Zrinski," "udario je nove temelje" gradu i "snažne zidine." ${ }^{44}$ Vjerojatno je ugarski plemić Dimitrius Csáky zasnovao Čakovec početkom 14. stoljeća, dok je Nikola IV. Zrinski za zasluge u borbi s Osmanlijama od kralja Ferdinanda 1546. dobio Međimurje i nakon toga dogradio postojeću utvrdu u Čakovcu pa se barem druga Evlijina tvrdnja slaže s podacima o povijesti grada. ${ }^{35}$ Evlija zatim navodi da su "nevjernički kraljevi s tisućama vojnika" ${ }^{36}$ mnogo puta bezuspješno opsjedali grad. Osmanlije ga nisu opsjedali, piše Evlija, ali su džebedžije ${ }^{37}$ opljačkali "varoš" (podgrađe, naselje podno utvrde), o čemu nema podataka. ${ }^{38}$ Evlija piše da Čakovec leži "na plodnom zemljištu obraslom zelenilom." ${ }^{39}$ Tollius je također za okolno područje napisao da je bilo plodno. ${ }^{40}$

Evlija navodi da se u zemlji Nikole VII. Zrinskog "nalaze vrlo razvijena mjesta"41 te da je zemlja Zrinskih "vrlo napredna i razvijena," a Čakovec i Legrad "jedni od najljepših gradova” Zrinskih i “čežnja svih vladara." ${ }^{42}$ Uveličavajući važnost Nikole VII., Evlija je zapisao da je "u staro doba" u rukama Nikole VII. bila "Aleksandrova kruna," pri čemu Evlija misli na Aleksandra Makedonskoga. Budući da Evlija u više navrata spominje Aleksandrovu krunu, navodeći da je, među ostalima, bila u

\footnotetext{
32 Pisana napomena Nenada Moačanina.

${ }^{33}$ Evliyâ Çelebi, Evliyâ Çelebi, sv. V, 274-275; Evlija Čelebi, Putopis, 244-247.

${ }^{34}$ Evliyâ Çelebi, Evliyâ Çelebi, sv. V, 273; Evlija Čelebi, Putopis, 244.

${ }^{35}$ Kalšan, Međimurska povijest, 56-57.

36 U Šabanovićevu prijevodu: “neprijatelji”. Evlija Čelebi, Putopis, 245.

${ }^{37}$ Rod osmanske vojske, vojnici oklopnici; brinuli su se o oružju i drugoj vojnoj logistici janjičarskih odreda. Abdulah Škaljić, Turcizmi u srpskohrvatskom jeziku (Sarajevo: Svjetlost, 1966), 234.

38 Evliyâ Çelebi, Evliyâ Çelebi, sv. V, 273-274; Evlija Čelebi, Putopis, 243-244.

39 Evliyâ Çelebi, Evliyâ Çelebi, sv. V, 275; Evlija Čelebi, Putopis, 247.

${ }^{40}$ Kuntić-Makvić, "Šesto putno pismo“, 153-154.

${ }^{41}$ Evliyâ Çelebi, Evliyâ Çelebi, sv. V, 272-273; Evlija Čelebi, Putopis, 242.

${ }^{42}$ Evliyâ Çelebi, Evliyâ Çelebi, sv. V, 279; Evlija Čelebi, Putopis, 255.
} 
posjedu bizantskih careva, habsburškoga cara i ugarskoga kralja, može se zaključiti da Evlija uporabom toga pojma nastoji dati vladarsku legitimaciju osobama koje spominje. Nikolu VII. naziva i hercegom i banom i kraljem. ${ }^{43}$ Tollius također spominje Aleksandra Velikoga kada opisuje zlatnike s njegovim likom u zbirci staroga novca u riznici Zrinskih u čakovečkom dvorcu. ${ }^{44}$ Navođenje antičkih uzora i uspoređivanje $s$ istima bila je odlika mnogih epoha europske povijesti pa se ista osobina ne bi trebala smatrati čudnom ni kod osmanskih intelektualaca kakav je bio Evlija.

Evlija tvrdi da je Čakovec udaljen dan jahanja od Drave. ${ }^{45}$ Čakovec je mogao biti najviše dva sata hoda udaljen od Drave. Možda je Evlija krivo procijenio jer je naknadno zapisivao svoje dojmove; za pretpostaviti je da nije bio u prilici zapisivati svoja zapažanja u pokretu, na konju, nego ih je zapisivao kasnije. Moguće je i da je iz nekoga drugog smjera preko Drave ušao u Međimurje. Čakovečku utvrdu opisuje kao "tvrd grad" peterokutnoga oblika "sazidan na način kako se podziđuju obale." ${ }^{6}$ Takav se opis u glavnim crtama slaže s prizorom čakovečke utvrde na veduti Johanna Ledentua iz 1639. godine na kojoj je dvorac prikazan kao četverokutna dvokatna građevina okružena peterokutnim zidinama i širokim jarkom. Najpoznatiji prikaz čakovečke utvrde jest crtež habsburškoga vojskovođe Raimonda Montecuccolija, koji je nastao vjerojatno između 1660. i 1664. godine, dakle u vrijeme Evlijina boravka u hrvatskim zemljama. Taj je crtež utvrde jednak Ledentuovoj veduti, iz čega možemo zaključiti da je utvrda zadržala svoj oblik od 1639. do 1660-ih godina, ${ }^{47}$ a izgled se slaže s Evlijinim opisom. Evlija, nažalost, ne iznosi daljnje podatke, na primjer o izgledu unutarnjega dvorišta dvorca (koji uzgred spominje), zatim broj katova dvorca, prostorije za smještaj vojnika ili dvostruki jarak, o kojima svjedoči prikaz Giovannija Giuseppea Spalle iz 1660-ih godina. ${ }^{48}$

Nakon što je Evlija s pratnjom odsjeo u "palači pored crkve bana Zrinskog," sutradan su mladi uniformirani službenici u kalpacima od samurovine došli po Evliju da ga odvedu "kralju." Evlija i njegova pratnja uzjahali su konje i uz pratnju vojnika i paževa krenuli su kroz grad razgledavajući ga. Kada su stigli u dvorište palače Zrinskih, ban mu je izašao pješice ususret, navodi Evlija, koji je tada sjahao i izljubio se s "banom." ${ }^{49}$ Raniji Evlijin opis banova poslanika koji ih je pratio na putu iz Moslavine za Čakovec, zatim opis stražara u Krčevini koji su ih propuštali

\footnotetext{
${ }^{43}$ Evliyâ Çelebi, Evliyâ Çelebi, sv. V, 272-273; Evlija Čelebi, Putopis, 77, 242.

${ }^{44}$ Kuntić-Makvić, "Šesto putno pismo", 153-155; Kalšan, Nikola Zrinski, 16.

45 Evliyâ Çelebi, Evliyâ Çelebi, sv. V, 275; Čelebi, Putopis, 247.

${ }^{46}$ Evliyâ Çelebi, Evliyâ Çelebi, sv. V, 275; Čelebi, Putopis, 247.

47 Ljerka Perči, "Vedute i planovi tvrđave Čakovec iz 17. stoljeća”, Muzejski vjesnik. Glasilo muzeja sjeverozapadne Hrvatske 10 (1987): 49-50, 52.

48 Kalšan, Nikola Zrinski, 15.

49 Evliyâ Çelebi, Evliyâ Çelebi, sv. V, 273-274; Evlija Čelebi, Putopis, 245.
} 
i oružane pratnje u Čakovcu podsjećaju na Tolliusov opis: nizozemski je učenjak zapisao da su njemu i grofu Pöttingu, rođaku Zrinskoga, u susret pred Čakovcem došli konjanici izviđači kako bi izvijestili Nikolu VII. o razlozima njihova dolaska. Jednu milju ispred grada dojahao im je u susret i sam Zrinski s pratnjom na konjima, sjahao i izgrlio ih, a zatim su kroz gustu vojničku predstražu ušli u čakovečki dvorac. $^{50}$

Evlija zatim opisuje kako ga je Nikola VII. odveo u "vijećnicu" gdje su sjeli na stolice s drugim "članovima vijeća." Dvorane dvorca nisu bile "zastrte ćilimima" nego su bile "obložene uglačanim i sjajnim komadićima mramora," odnosno "mozaikom i sjajnim tvrdim mramorom" u Šabanovićevu prijevodu. ${ }^{51}$ Možda Evlija naglašava postojanje mramora i stolica jer svojim pretpostavljenim čitateljima naviklima na orijentalni interijer - tumači razlike koje je uočio: prostorije nisu zastrte ćilimima i nitko ne sjedi na podu kako je u orijentalnim kulturama uobičajeno. Prema opisu dvorca na temelju podataka iz 1638. godine $e^{52}$ može se zaključiti da su se u dvorcu nalazile tri velike dvorane, od kojih je jedna mogla biti mjesto njihova razgovora. Što se tiče podnoga mramora koji Evlija opisuje, povijesnoumjetnička studija Petra Puhmajera upućuje na mogućnost da se radilo o uglačanim kamenim podovima tipa terrazzo i da je Evlija vidio terrazzo sa šljunkom ili komadićima raznolikoga kamenja koje može podsjećati na mozaik. ${ }^{53}$ Evlija nam ne daje posebno sadržajan opis unutrašnjosti palače Zrinskih. Možda zbog toga što je interijer zbog položaja palače na habsburško-osmanskome pograničju bio pod velikim utjecajem orijentalnoga stila u namještaju ${ }^{54} \mathrm{i}$ time nije na njega ostavio poseban dojam, a možda zbog toga što je Evlija bio pod dojmom susreta i razgovora sa Zrinskim kako nam i sam navodi. Tvrdi da je bio zastrašen osobnošću Nikole VII., ali da je prikupio hrabrost i predao banu u ruke pismo. Tollius je u svojemu opisu Nikole VII. govorio baš o tome strahu koji je Zrinski izazivao među Osmanlijama zapisavši da se "u Turaka dječji plač zaustavlja samom riječju da Zrinski ide (...)." ${ }^{55}$ Evlija kaže da je ban poljubio pismo, prislonio ga na čelo i zatim predao prevoditeljima koji su stajali u blizini. Nakon što je saslušao prijevod sadržaja pisma, upitao je Evliju gdje je blago koje je tražio za otkupninu. Evlija je slugama dao znak da dovezu i izlože sadržaj dvanaest srijemskih kola

\footnotetext{
${ }^{50}$ Kuntić-Makvić, “Šesto putno pismo", 153-154.

${ }^{51}$ Evliyâ Çelebi, Evliyâ Çelebi, sv. V, 274; Evlija Čelebi, Putopis, 245.

${ }^{52}$ Ana Sekso (prijevod), "Széchyjev opis dvorca Zrinski prema starim spisima", u: Petar Puhmajer, Čakovec. Stari grad - Novi dvor. Povijesno-umjetnička studija (Zagreb: Hrvatski restauratorski zavod, služba za nepokretnu baštinu, 2006), 54.

${ }^{53}$ Puhmajer, Čakovec, 20.

${ }^{54}$ Rajka Modrić (sabrala, predgovorom i kazalom popratila), Povijesni spomenici obitelji Zrinskih i Frankopana $=$ Monumenta historica familiarum Zrinski et Frankopan, sv. 1: Popisi i procjena dobara (16721673 ) = Conscriptiones et aestimationes bonorum (1672-1673) (Zagreb: Jugoslavenska akademija znanosti i umjetnosti, 1974), passim.

${ }^{55}$ Kuntić-Makvić, "Šesto putno pismo", 153; Kalšan, Nikola Zrinski, 15.
} 
koje su pred banom "komad po komad" prebrojali radi usporedbe s popisom koji je ban otposlao te su ih predali banovu službeniku. Otkupnina se sastojala od samurovine i crvenoga dijarbakirskog ${ }^{56}$ platna u vrijednosti od četrdeset tisuća groša, tisuću bala platna za dimije (ženske široke hlače), tisuću bala perzijskoga platna boje kamforovca, tisuću bala crvene strumičke ${ }^{57}$ tkanine, dvjesta pokrivača, tisuću žutih i tisuću crvenih sahtijana (kozjih koža), tisuću pari crvenih i tisuću pari žutih čizama, tisuću pari papuča, tisuću pari lakih cipela, tisuću pari košulja i druge robe. Melek Ahmed-paša poslao je i pismo za Nikolu VII. te kao poklon sedžadu (molitveni ćilim), svilom izvezenu haljinu i kožu od samurovine podstavljenu crvenom čohom. ${ }^{58}$ Zrinski je zatim upitao zašto nije poslano četrdeset konja koje je tražio od Melek Ahmed-paše, a Evlija je odgovorio da konji nisu poslani jer "naši [valjda arapski] konji ne mogu živjeti u ovoj studenoj zemlji." 59 U zamjenu je paša poslao dodatnih pet krzna od samurovine. Tollius je opisao strast Nikole VII. prema konjima jer je ban osobito hvalio svoga konja i njegovu brzinu. ${ }^{60}$ Valjda je zato i tražio konje od Melek Ahmed-paše, osobito arapske konje poznate po svojoj brzini. Ban je izjavio da ga Melek Ahmed-paša "jako voli” - a ne da on jako voli Melek-pašu, kako stoji u Šabanovićevu prijevodu. ${ }^{61}$ Evlija je zatim zatražio da im Nikola VII. dovede Mustaj-bega. Zarobljenik je "s mukom" ušao u dvoranu jer je bio okovan " 27 oka $^{62}$ teškim željeznim okovima na nogama," a ne "12 oka" kao kod Šabanovića. ${ }^{63}$ Kada je Evlija zatražio da Nikola VII. bihaćkoga kapetana oslobodi okova, Zrinski je odvratio da će to učiniti ako se Mustaj-beg zakune Djevicom Marijom (Mariya Ana = Majka Marija) da više neće "paliti, robiti i pustošiti naš vilajet." ${ }^{64}$ Ako Mustaj-beg to ipak nastavi činiti, zaprijetio je Zrinski, “(...) neću ga kao sad zarobiti. Ako mi još jednom dopadne ruku, ubit ću ga i kožu mu oderati!"”5 Evlija je na to rekao: "Takvo je stanje na krajini. I vi udarate na njihovu zemlju pa i oni na vaše gradove." Svoj je odgovor zaključio refleksivnim komentarom: "Takav je običaj, svijet je lakrdija." 66

\footnotetext{
${ }^{56}$ Diyarbakır, grad u Turskoj.

57 Strumica, grad u Makedoniji.

${ }^{58}$ Evliyâ Çelebi, Evliyâ Çelebi, sv. V, 261-262; Evlija Čelebi, Putopis, 215.

${ }^{59}$ Evliyâ Çelebi, Evliyâ Çelebi, sv. V, 274; Evlija Čelebi, Putopis, 246.

${ }^{60}$ Kuntić-Makvić, "Šesto putno pismo", 155.

${ }^{61}$ Treba imati u vidu da je Šabanovićev prijevod temeljen na vrlo manjkavome osmanskom izdanju i da je bosansko-hercegovački orijentalist u premoćnoj većini slučajeva vrlo uvjerljivo preveo osmanski predložak, a s njime, nažalost, i slučajeve pogrešne transliteracije Evlijina izvornika. Evliyâ Çelebi, Evliyâa Çelebi, sv. V, 274; Evlija Čelebi, Putopis, 246.

${ }^{62}$ Mjera za težinu i tekućinu (1,282 kilograma; 1,5 litara).

${ }^{63}$ Evliyâ Çelebi, Evliyâ Çelebi, sv. V, 274-275; Evlija Čelebi, Putopis, 246; Moačanin, Jurin Starčević, “Novi' Evlija”, 84.

${ }^{64}$ Evliyâ Çelebi, Evliyâ Çelebi, sv. V, 275; Evlija Čelebi, Putopis, 246.

${ }^{65}$ Moačanin, Jurin Starčević, “'Novi’ Evlija”, 88; Evliyâ Çelebi, Evliyâ Çelebi, sv. V, 275.

${ }^{66}$ Evliyâ Çelebi, Evliyâ Çelebi, sv. V, 275; Evlija Čelebi, Putopis, 246; Moačanin, Jurin Starčević, “'Novi’ Evlija", 77.
} 
Evlija opisuje Nikolu VII. kao velikodušnoga domaćina. Nakon što su Mustaj-begu skinuli okove, Evlija je zatražio od Zrinskoga da ne otpušta bega "ovako gola" nego da mu pokloni odijelo, konja i okove koje su mu netom skinuli. Ban mu je dao odijelo, ogrtač od samurovine, konja sa sedlom, koje je s unutarnje strane bilo izvezeno srebrom i okove. Nakon toga priređena je velika gozba tijekom koje se ban obratio Mustaj-begu s "nekoliko prijateljskih riječi." ${ }^{67}$ Potom je bihaćki kapetan dobio banovo dopuštenje da ode i zaputio se iz Čakovca s $1060^{68}$ vojnika, a Evlija je s 400 konjanika ostao "razgovarati" s banom i "razgledati grad." ${ }^{69}$ Ban je osmanskome gostu darovao "krajiški" krzneni ogrtač od samurovine, odijelo i konja. ${ }^{70}$ Evlija je na spomenutim poklonima banu uzvratio poslavši mu svilenu i umjetnički izrađenu sedžadu, svilenu skupocjenu "haljinu za divan" i krzneni ogrtač od samurovine prekriven čohom boje jorgovana, što ih je banu poslao Melek Ahmed-paša. ${ }^{71}$ Istočnjački ćilimi bili su uobičajeni dio unutarnjega uređenja dvorca Zrinskih. ${ }^{72}$ Hrvatsko plemstvo na habsburško-osmanskoj granici u svojoj je svakodnevici često i živo komuniciralo s neprijateljskom stranom unatoč ratnome stanju. Evlijin opis razgovora s Nikolom VII. ide u prilog takvoj slici. Zrinski je navodno pred Evlijom za Mustaj-bega rekao da je "hrabar čovjek i junak," da mu se nazdravljalo diljem Habsburškoga Carstva i da ga se spominjalo u pjesmama. ${ }^{73}$ Otkupljivanje zarobljenika uz obilne otkupnine bio je vrlo čest običaj na pograničju ${ }^{74}$ kao i razmjenjivanje osobnih poklona i pisama. Nikola VII. je Evliji na odlasku predao pisma za Melek Ahmed-pašu, ${ }^{75}$ što potvrđuje navode o živoj pismenoj komunikaciji između visokih dužnosnika na razmeđi dvaju carstava. Tollius opisuje veliki broj osmanskih zarobljenika u tamnici čakovečkoga dvorca i njihovo kažnjavanje u slučaju da nisu mogli ili nisu željeli platiti otkupninu. Zarobljeni osmanski age, njih osmorica prema Tolliusovu kazivanju, bili su dobro hranjeni, ali i otkupljivani u zlatu. Za razliku od pomirljivijega tona Evlijina Putopisa Tollius opisuje postupanje Nikole VII. sa zarobljenicima kao potrebito na habsburško-osmanskoj granici jer "s Turcima se drugačije ne može živjeti." ${ }^{76} \mathrm{U}$

\footnotetext{
${ }^{67}$ Evliyâ Çelebi, Evliyâ Çelebi, sv. V, 275; Evlija Čelebi, Putopis, 246.

${ }^{68}$ Vidjeti bilješku br. 12.

69 Evliyâ Çelebi, Evliyâ Çelebi, sv. V, 275; Evlija Čelebi, Putopis, 247.

70 Evliyâ Çelebi, Evliyâ Çelebi, sv. V, 275; Evlija Čelebi, Putopis, 247.

${ }^{71}$ Evliyâ Çelebi, Evliyâ Çelebi, sv. V, 275; Evlija Čelebi, Putopis, 247.

72 Žarka Vujić, “Baštinski svijet Nikole Zrinskog u Čakovcu”, u: Zrinski i Europa, ur. Jadranka Damjanov, (Zagreb: Društvo mađarskih znanstvenika i umjetnika u Hrvatskoj, 2000), 24.

73 Evliyâ Çelebi, Evliyâ Çelebi, sv. V, 275; Evlija Čelebi, Putopis, 247. Treba napomenuti da je Mustaj-beg Hasumović poistovjećivan s ličkim sandžakbegom Mustaj-begom Ličkim, junakom muslimanskih narodnih pjesama.

74 Antun Šimčik, “Bilježnica sisačkoga špana Jurja Turjaka kanonika zagrebačkog iz g. 1649.”, Vjesnik Kraljevskog državnog arkiva u Zagrebu 6 (1934): passim.

75 Evliyâ Çelebi, Evliyâ Çelebi, sv. V, 276; Evlija Čelebi, Putopis, 250.

${ }^{76}$ Kuntić-Makvić, “Šesto putno pismo”, 153-156.
} 
popisu dobara Zrinskih u čakovečkoj utvrdi iz 1673. godine nabrajaju se i okovi korišteni za sputavanje i kažnjavanje osmanskih zarobljenika. ${ }^{77}$

"Palača" u kojoj je Nikola VII. ugostio Evliju i njegovu pratnju opskrbljena je s "pedeset ovaca, sto kokoši, dva kaveza golubova, tisuću bijelih kruhova ${ }^{78}$ i deset kuhara koji su služili u kuhinji," zapisao je Evlija. ${ }^{79}$ Poznato je da je obitelj Zrinski na svojim posjedima među ostalim uzgajala ovce, kokoši i golubove te proizvodila vrlo kvalitetan pšenični kruh s kvascem. ${ }^{80}$ Osim toga, u kuharici Kratki zapis o kuhanju općepoznatih jela, za koju je moguće da ju je napisao glavni kuhar čakovečkoga dvorca, opisani su brojni recepti s ovčetinom, piletinom i golubljim mesom. Dvor Zrinskih svakako je bio u mogućnosti obilno, raskošno i ukusno nahraniti ugledne goste. ${ }^{81}$ Takvim bi se i Evlija mogao nazvati jer je došao s delikatnom zadaćom otkupa zarobljenika kao izaslanik visokoga osmanskog zapovjednika. Erdeljski državnik i književnik Miklós Bethlen u djelu Autobiografija opisao je svoj posjet Čakovcu i zapisao da je Nikola VII. svim uglednim gostima osiguravao ugodan smještaj u dvorcu, a njihovim slugama "vanjsku kuću u gradu, dobro konačište i poštenu obilnu hranu." ${ }^{82}$

Evlija je zapisao da je Nikola VII. optužio osmanske zapovjednike da nisu poštivali mirovni ugovor između dva carstva jer su osmanski odredi upadali na hrvatsko područje i pustošili ga. "Zašto turski ${ }^{83}$ vezir ne zauzda [svoje vojnike]," ${ }^{84}$ navodno je upitao Nikola VII., pri čemu je možda mislio na osmanskoga velikog vezira Köprülü Mehmed-pašu, a možda na kaniškoga beglerbega Söhrab Mehmed-pašu, kako nam Evlija sugerira. Evlija je banu uzvratio rekavši da i kršćanski vojnici djeluju suprotno mirovnome ugovoru jer ni "njemački cesar" ne može obuzdati "vaše vojnike što stalno dolaze u gradove Bihać, [danas Bosansku] Krupu, Udbinu i Liku ${ }^{85}$ te pljačkaju i pustoše, uzimaju plijen i odvode roblje, a bihaćki je kapetan

\footnotetext{
${ }^{77}$ Ivan Jurišić, "Ostaci dobara Zrinskih nakon konfiskacije, prema popisu i procjeni 1672-1673., na primjeru utvrde Čakovec i popisa njenog inventara od 9. svibnja 1673.," u: Povijest obitelji Zrinski. Zbornik, ur. Zoran Ladić, Đuro Vidmarović (Zagreb: Matica hrvatska, 2007), 86-87.

${ }^{78}$ Sipov ekmeği, vrsta mađarskoga bijelog kruha; rumelijski (balkanski) osmanski naziv dolazi od mađarske riječi za manju okruglu štrucu kruha. Dankoff, Evliya Çelebi Seyahatnamesi, 209.

${ }^{79}$ Evliyâ Çelebi, Evliyâ Çelebi, sv. V, 275; Evlija Čelebi, Putopis, 247.

${ }^{80}$ Rudolf Horvat, “Zapljena Zrinskih imanja”, Hrvatsko kolo 4 (1908): 186; Jurišić, “Ostaci dobara Zrinskih", 84.

${ }^{81}$ Iván Sándor Kovács, “Želučana materia”, u: Zrinski i Europa, ur. Jadranka Damjanov (Zagreb: Društvo mađarskih znanstvenika i umjetnika u Hrvatskoj, 2000), passim; Zlatko Puntijar, Matea Puntijar, prir., Kuharska knjiga Čakovečkog dvora Zrinskih u rukopisu i prijevodu iz vremena Nikole grofa Zrinskog ban hrvatski 1647.-1664. (Zagreb: V. O. Stari Puntijar, 2007), 6-8.

${ }^{82}$ Kovács, "Želučana materia", 351; Kalšan, Međimurska povijest, 99; Kalšan, Nikola Zrinski, 13.

${ }^{83}$ U Šabanovićevu prijevodu pogrešno je prevedeno: "Zašto Juruk (skitnica) vezir ne zauzda svoje vojnike?” Moačanin, Jurin Starčević, öNovi’ Evlija”, 86.

${ }^{84}$ Evliyâ Çelebi, Evliyâ Çelebi, sv. V, 276; Evlija Čelebi, Putopis, 248.

${ }^{85}$ Nije poznato na koji grad Evlija misli pod imenom "Lika." Šabanović pretpostavlja da se radi o mjestima Ribnik, Kula ili Ostrovica jer Evlija za "Liku" kaže da se nalazi na obali Une. Moguće je da se radi o nekome drugom mjestu koje se ne nalazi na toj rijeci, npr. Kulen Vakufu, koji se nalazi u neposrednoj
} 
tek otišao izbavljen iz ropstva.” Evlija tvrdi da mu je Zrinski uzvratio obrativši mu se, kako Šabanović slikovito prevodi, riječima: "Ah, Turčine li Turčine [sigurno si i ti] po ovim našim krajinama mnogo četovao, jatakovao, junačio i prebjegavao..." Zrinski je dodao da su kršćanske snage zarobile 300 osmanskih vojnika u Kaniškome sandžaku i ubile sina kaniškoga bega Boynueğrija Mehmed-paše. ${ }^{86}$ Evlija je izjavio da se kaniški vojnici osvećuju zbog kršćanskih napada, a kršćanski vojnici zbog osmanskih te da se neprestano žale jedni na druge. Zrinski mu je na to odgovorio: "Evlija-aga, ovo je jatak naše krajine. O tome se ne može dovoljno govoriti [odnosno, riječi ne mogu opisati]. To reče i ušuti." ${ }^{77}$ Zrinski se Evliji "mnogo žalio" i na osmanske vojnike iz Kaniškoga, Hercegovačkoga i Požeškoga sandžaka ${ }^{88}$ Evlija je branio spomenutoga Söhraba Mehmed-pašu kada su se pred Zrinskim na osmanskoga zapovjednika požalili banovi podanici. Mehmed-pašine čete "neprestano" su pljačkale uzduž Mure te pobile 300, a zarobile 200 stanovnika u "gradu Peški na Muri” kako ga naziva Šabanović, odnosno u mjestu Yeleşke, kako je ime toga naselja transliterirano u autografu. ${ }^{89}$ Nije poznato o kojemu se mjestu radi. Makar imali na umu da je Evlija mogao izmisliti ovakav živopisan razgovor sa Zrinskim, zanimljiv je pomirljiv ton kojim Evlija opisuje turbulentno stanje na habsburško-osmanskoj granici.

Sljedećega dana Zrinski i Evlija s pratnjom otišli su u Legrad, čije ime Evlija iz (zasad) nepoznatoga razloga koristi u deminutivu i konstantno ga naziva Legradcık (“maleni Legrad")..${ }^{90}$ Žitelji legradske utvrde zbog banova dolaska okitili su njezine zidove crvenom vunenom tkaninom, a bastione zastavama. Iz crkava su zvonila zvona i "sva je vojska izašla da dočeka bana" klanjajući mu se do poda, zapisao je Evlija. Dok su prolazili Legradom, “[č] ovjeku se mozak opijao od mirisa aloe, ambre i tamjana, što se razvijahu iz zlatnih i srebrenih kadionica po ulicama." Gradski prvaci priredili su gozbu: "Svakome je dano toliko jela i nesretnog vina da se nijedan nije mogao držati na nogama." ${ }^{91}$ Petar Zrinski je u djelu Adrianskoga mora sirena preveo s mađarskoga na hrvatski pjesme svoga brata Nikole. U jednoj pjesmi govori o slavlju tijekom kojega se obilno pilo "rujno" vino do opijenosti kada se "na vse strani misli odpustihu" i počele su se pjevati davorije i plesati "hajdučki ples."92

blizini utvrde Ostrovica. Evlija Čelebi, Putopis, 76, 221. Nenad Moačanin smatra da se radi o današnjemu Ličkom Ribniku. Nenad Moačanin, Turska Hrvatska. Hrvati pod vlašću Osmanskoga Carstva do 1791. Preispitivanja (Zagreb: Matica hrvatska, 1999), 40.

${ }^{86}$ Boynueğri ili Boynuyaralı Mehmed-paša, osmanski visoki vojni zapovjednik i veliki vezir od travnja do rujna 1656. godine. İsmail Hakkı Uzunçarsılı, Osmanlı Tarihi III, sv. 2: XVİ. Yüzyıl Ortalarından XVİI. Yüzyll Sonuna kadar (Ankara: Türk Tarih Kurumu, 1954), 412-414.

${ }^{87}$ Evliyâ Çelebi, Evliyâ Çelebi, sv. V, 276; Evlija Čelebi, Putopis, 248.

${ }^{88}$ Evliyâ Çelebi, Evliyâ Çelebi, sv. V, 276; Evlija Čelebi, Putopis, 248.

${ }^{89}$ Isto, 248; Evliyâ Çelebi, Evliyâ Çelebi, sv. V, 276.

${ }^{90}$ Evliyâ Çelebi, Evliyâ Çelebi, sv. V, 276; Evlija Čelebi, Putopis, 248.

${ }^{91}$ Evlija Čelebi, Putopis, 248, 249; Evliyâ Çelebi, Evliyâ Çelebi, sv. V, 276.

${ }^{92}$ Kovács, “Želučana materia”, 348. 
Evlija tvrdi da se u Legradu nalazilo mnogo vinograda i vrtova te da je grad bio "napredan i uređen [te] čist." Evlija navodi da je Legrad bio manji od Čakovca, ali ne spominje broj kuća. ${ }^{93}$ Evlija tvrdi i da riječ "grad" znači "utvrda" i nabraja gradove s tom riječju u nazivu (Beograd, Višegrad, Kamengrad, Novigrad itd.) povezujući tu riječ s imenom Legrada. ${ }^{94}$ Legrad naziva "gradom nevjesti" jer je zapazio da u Legradu "djevojke sjede u svim dućanima i svaka od njih posve otkrivena i lijepa kao vila i poput anđela prodaje trgovačku robu. Ovdje nije sramotno prodavati robu." 95 Vjerojatno mu je taj prizor privukao pozornost zbog toga što je u osmanskome svijetu zbog vjerskih pravila nepokrivanje žena i njihovo trgovanje bilo zabranjeno. Evlijin opis trgovačkih djelatnosti u Legradu i gradski izgled njegovih ulica u skladu je s onovremenim stanjem u Legradu koji je, iako selo premaleno da bi se nazivalo gradom, bio trgovište s razvijenim obrtima i trgovinskom razmjenom, koja je sezala na obje strane habsburško-osmanske granice, a njegovi stanovnici u nekoliko su navrata tijekom 17 . stoljeća nazivani građanima. ${ }^{96}$

Idućega jutra Zrinski je poveo Evliju u lov u Krčevinu kamo su putovali "punih sedam sati." Iz toga bi se moglo zaključiti da se mjesto lova nije nalazilo u blizini Legrada, na primjer na Legradskoj gori, kako tvrdi Dragutin Feletar. ${ }^{97}$ Evlija opisuje kako su banovi ljudi otišli ranije i obavijestili "raju," podanike seljake da podignu galamu pucanjem iz topova. "More ljudi" stvorilo je "zaglušnu buku" i satjeralo u Krčevinu divlje životinje. Bili su tu jeleni "veliki kao slonovi," jeleni lopatari, "neka vrsta medvjeda crvene dlake," "strašni veliki zubati veprovi bijahu veći od magarca," divlje koze ili divokoze, ${ }^{98}$ ovce "velike kao govedo" i mnogo lisica, šakala, vukova, "hijena" i zečeva. Seljaci su se sjatili i počeli ih ubijati i tako proveli uspješan lov. ${ }^{99}$ Poznato je da su Zrinski vrlo često išli u lov na divlje životinje, a Nikola VII. poginuo je u lovu prilikom napada vepra četiri godine nakon Evlijina posjeta. ${ }^{100}$ Kuharica s dvora u Čakovcu upućuje na to da se ondje jelo mnogo divljači. ${ }^{101}$ I Tollius i Bethlen posvjedočili su da je Nikola VII. jako volio lov. Tollius je sudjelovao u lovu na srne, zečeve, jarebice i prepelice. ${ }^{102}$

\footnotetext{
${ }^{93}$ Evliyâ Çelebi, Evliyâ Çelebi, sv. V, 276.

${ }^{94}$ Evliyâ Çelebi, Evliyâ Celebi, sv. V, 276.

${ }^{95}$ Evliyâ Çelebi, Evliyâ Çelebi, sv. V, 276.

${ }^{96}$ Feletar, “Zrinski Legrad”, 182-183; Petrić, Feletar, Feletar, Novi Zrin, 17.

${ }_{97}$ Dragutin Feletar, “Još nekaj o Legradskoj gori, s opisom lova iz 1660., Dobravske novine 46 (2016): 22.

${ }^{98}$ Nikola VII. jednom je prilikom svojemu prijatelju i mađarskome grofu Ádámu Batthyányju (1610. 1659.) poslao divokozu kao poklon. Kovács, Evliyâ Çelebi, Evliyâ Çelebi, 347.

${ }^{99}$ Šabanović je riječ "hijena" preveo riječju "ris." Možda je pretpostavljao da bi se ta životinja mnogo vjerojatnije mogla sresti na spomenutome području. Evliyâ Çelebi, Evliyâ Çelebi, sv. V, 276; Evlija Čelebi, Putopis, 250.

${ }^{100}$ Kalšan, Međimurska povijest, 117.

${ }^{101}$ Puntijar, Puntijar, Kuharska knjiga, passim.

${ }^{102}$ Kuntić-Makvić, "Šesto putno pismo", 155; Kovács, “Želučana materia”, 352.
} 
Evlija tvrdi da mu je ban na odlasku predao kao poklon za Meleka Ahmed-pašu kočiju sa šest konja, s oslikanim staklima i podstavljenu baršunom, dvadeset zlatom izvezenih pušaka s futrolama, deset topova prekrivenih platnom, stotinu ukrašenih njemačkih ćilima, deset koža natopljenih mošusom, deset koža njemačkih medvjeda, šarene štavljene kože "njemačkoga losa" i deset "potpuno naoružanih" muslimanskih robova na konjima, za koje je Zrinski rekao: "Za pašinu sreću dajem im slobodu." Evliji je poklonio svežanj novca za putni trošak, tkaninu za desetore hlače, dvadeset ukrašenih pušaka, pet mirišljavih koža, pet ćilima, dvadeset krzana njemačkoga jelena mošutnjaka; Evlijinim slugama poklonio je po dvadeset novčića, krajišnicima koji su dopratili Evliju vrećicu novčića, a kapetanu spomenutih krajišnika jednu tkaninu. ${ }^{103}$ Iako Evlijino nabrajanje poklona zvuči pretjerano, može se zaključiti da su Zrinski doista posjedovali predmete slične ili jednake gore opisanima. Prema popisu dobara Zrinskih u čakovečkoj utvrdi iz 1673. godine može se zaključiti da su Zrinski posjedovali veći broj različitih kočija, razne vrste životinjskih koža kao i razne skupocjene tkanine, među ostalim izvezene zlatom i od baršuna, dragocjene ćilime, pozlaćene predmete, ukrasno oružje i tako dalje. ${ }^{104}$ Tijekom pljačke imanja Zrinskih 1670. godine, nakon što je habsburški car Leopold I. proglasio Petra Zrinskoga i Frana Krstu Frankopana neprijateljima države, počinitelji su, među ostalim, uzeli dvije kočije sa šest pari zaprežnih konja i "kristalnu" kočiju s tri para konja, dragocjene ćilime i mačeve, staklene prozore, raznu odjeću od baršuna, odjevne predmete od sobolovine, ukrasno oružje i konjsku opremu (pokrivače) od baršuna izvezenu srebrom. ${ }^{105}$ Nikola VII. svoju je darežljivost iskazao i prilikom Tolliusova odlaska - poklonio mu je "tri turske knjige," tri rupca, od toga jedan ukrašen zlatom i srebrom, te skupocjenu sablju, a rođaku Pöttingu "turskoga" (valjda arapskoga) konja i poklone njegovim slugama. ${ }^{106}$ Sve u svemu, Evlijini opisi poprilično se slažu s iskazima drugih posjetitelja o inventaru čakovečkoga dvorca i bogatstvu Zrinskih.

Osmanska vojska iz Kaniže osobito je u 1640-ima upadala u Međimurje, pljačkala lokalno stanovništvo i odvodila ih u roblje. Evlija opisuje brojne osmanske upade na područje današnje Slavonije, Dalmacije, središnje i sjeverne Hrvatske (te dijelove Hrvatske naziva Hirvadistan), Međimurje i Korušku. Evlija tvrdi da su Osmanlije ondje harali i odnijeli "bezbroj roblja i mnogo ratnog plijena" $\mathrm{u}$ listopadu i studenome 1660. godine te u svibnju i lipnju 1664. godine. ${ }^{107}$ Međimurje je na svojoj istočnoj granici uz Muru i Dravu bilo štićeno nizom čardaka, odnosno stražarnica koje su služile za nadzor osmanskih upada.

\footnotetext{
${ }^{103}$ Evliyâ Çelebi, Evliyâ Çelebi, sv. V, 276; Evlija Čelebi, Putopis, 250.

${ }^{104}$ Jurišić, "Ostaci dobara Zrinskih", 81, 85, 87.

${ }^{105}$ Horvat, "Zapljena Zrinskih imanja”, 195.

${ }^{106}$ Kuntić-Makvić, "Šesto putno pismo", 158.

${ }^{107}$ Evliyâ Çelebi, Evliyâ Çelebi, sv. V, 279; sv. VI, 318; Evlija Čelebi, Putopis, 255, 489.
} 
Zrinski su nosili titule kapetana Međimurja i Legrada i time su bili zapovjednici vojnih odreda u mjestima Legrad, Kotoriba, Hodošan i Goričan, koja se nalaze uz desnu obalu Mure i u vrijeme Evlijina posjeta činila su južni dio pogranične obrambene linije usmjerene prema Kaniži kao najbližemu osmanskom gradu. $\mathrm{Na}$ karti Giovannija Giuseppea Spalle iz 1670. godine uz Muru ucrtano je devetnaest čardaka, a na karti Giacoma Cantellija iz 1690. godine nalazi se jedanaest manjih utvrda ili stražarnica, dok je u drugim izvorima zabilježeno četrnaest vojnih objekata uz Muru. ${ }^{108}$ Ako se na prostoru od današnjega Podturna do ušća Mure u Dravu na udaljenosti od otprilike 45 kilometara nalazilo devetnaest stražarnica, to bi značilo da se na svakih dva do dva i pol kilometra udaljenosti nalazio po jedan čardak. "Iako postoje stražarnice uz Muru, zbog velike udaljenosti među njima kontrola terena je nemoguća," ustvrdio je Nikola VII. u pismu poslanome 1642. godine caru Ferdinandu II. ${ }^{109}$ Evlija je zapisao da je Nikola VII. uzduž hrvatske granice s Osmanskim Carstvom razmjestio stražarnice međusobno udaljene "koliko top može dobaciti." ${ }^{110}$ Takve kule bile su sagrađene i uz desnu obalu Mure, tvrdi Evlija, i upozoravale su cijelo okolno područje na prisutnost neprijatelja tako što su ispaljivale topovske hice. ${ }^{111}$ Bilo je teško zaustaviti česte osmanske upade u Međimurje, posebice uokolo Novoga Zrina između 1660. i 1664. godine. ${ }^{12}$ Nikola VII. pojačao je straže na Muri i s tristo konjanika vodio ophodnje uzduž rijeke, a u studenome 1663. porazio je tatarsku vojsku od dvije tisuće vojnika zajedno s lokalnim osmanskim odredima iz Kaniže koji su namjeravali napasti Međimurje. ${ }^{113}$ Evlija opisuje upravo jedan od takvih prelazaka tatarskih odreda preko Mure u Međimurje, tijekom kojega su posade najbližih stražarnica primijetile prolazak neprijateljske konjice i počele pucati iz topova "tako da je grmljavina topova uzdrmala svu dušmansku pokrajinu, te se na sve strane saznalo o nama."114

Evlija iscrpno opisuje opsadu Novoga Zrina, utvrde koju je Nikola VII. dao izgraditi 1660. godine na lijevoj obali Mure blizu ušća u Dravu. Evlija ju dosljedno naziva "Novom Utvrdom" ("Yeni Kale"), odnosno Novigradom u Šabanovićevu prijevodu i ne spominje ime Zrin. ${ }^{115}$ Osmanlije su se neprestano žalili na postojanje Novoga Zrina jer je bio podignut na teritoriju Kaniškoga sandžaka, što je bilo

\footnotetext{
${ }^{108}$ Ljerka Perči, "Neki prikazi tvrđave Legrad iz 16. i 17. stoljeća”, Muzejski vjesnik. Glasilo muzeja sjeverozapadne Hrvatske 9 (1986): 15; Petrić, Feletar, Feletar, Novi Zrin, 18-26; Kalšan, Međimurska povijest, 62-63, 84-85, 99; Kalšan, Nikola Zrinski, 14.

${ }^{109}$ Isto, 6-7, 9.

${ }^{110}$ Evliyâ Çelebi, Evliyâ Çelebi, sv. V, 279; Evlija Čelebi, Putopis, 255.

${ }^{111}$ Evliyâ Çelebi, Evliyâ Çelebi, sv. V, 317; Evlija Čelebi, Putopis, 486.

${ }^{112}$ Petrić, Feletar, Feletar, Novi Zrin, 66-69.

${ }^{113}$ Kalšan, Nikola Zrinski, 19-20.

${ }^{114}$ Evliyâ Çelebi, Evliyâ Çelebi, sv. V, 317; Evlija Čelebi, Putopis, 486.

${ }^{115}$ Evlija Čelebi, Putopis, 452, 473.
} 
suprotno tadašnjemu habsburško-osmanskom mirovnom ugovoru. ${ }^{116}$ Osmanlije su 7. lipnja 1664. pod zapovjedništvom velikoga vezira Köprülüa Fazıla Ahmedpaše započeli trotjednu opsadu Novoga Zrina. ${ }^{117}$ Prilikom prolaska pored Zagreba u lipnju 1664. godine Evlija je doznao da je Zagreb bio pust jer je "sva vojska otišla u Novi Zrin boriti se s Turcima." 118 Hrvatski je sabor u prosincu 1663. - s ciljem organiziranja odreda koji su sudjelovali u zimskome vojnom pohodu Nikole VII. Zrinskog u južnoj Mađarskoj - u siječnju i veljači 1664. godine proglasio opću mobilizaciju. ${ }^{119}$ Evlijina primjedba o Zagrebu govori nam da se mobilizacija hrvatskih snaga ponovila i tijekom opsade Novoga Zrina. Evlija opisuje kako je odlazak svih raspoloživih hrvatskih odreda u borbe pod Kanižom i Novim Zrinom imao za posljedicu nesmetano haranje osmanskih odreda diljem tadašnje Slavonije. Tako Evlija tvrdi da je u sastavu osmanskoga odreda harao po tadašnjoj zapadnoj Slavoniji i Podravini gdje su se susreli s odredom iz Požege i Đakova, koji je ondje palio i porobljavao. ${ }^{120}$ Evlija je zapisao da se zvuk topovske paljbe što je dolazio iz smjera Novoga Zrina u vrijeme osmanske opsade u svibnju i lipnju 1664. čuo kilometrima daleko po okolnim hrvatskim krajevima. ${ }^{121}$

Što se tiče same opsade Novoga Zrina, Evlija uglavnom potvrđuje kršćanske opise opsade prema kojima je utvrda bila pod stalnom topovskom paljbom prije konačnoga općeg juriša osmanskih snaga 30. lipnja. ${ }^{122}$ Evlija opisuje kako su drveni trupci palisade uokolo utvrde bili povezani cementom i vapnom. Ta se smjesa toliko odupirala topovskim hicima da je utvrda "gutala kugle kao med,"123 ali paljba nije "nanijela toliko štete koliko grebotina nokta." ${ }^{124}$ Evlijin opis trupaca u skladu je s podatkom da je barun d'Avancourt, zapovjednik obrane Novoga Zrina, dao ojačati bedeme izgradnjom palisade od hrastovine, koju su topovske kugle teško probijale. ${ }^{125}$ Evlija opisuje "razne prepreke i zamke" ${ }^{126}$ koje su branitelji postavljali pred nadirućim osvajačima, što se posve slaže s rezultatima arheoloških istraživanja mađarskih znanstvenika na lokaciji utvrde. ${ }^{127}$ Evlija navodi da su Osmanlije

\footnotetext{
${ }^{116}$ Evlija Čelebi, Putopis, 452.

${ }^{117}$ Petrić, Feletar, Feletar, Novi Zrin, 85; Kalšan, Medimurska povijest, 114; Kalšan, Nikola Zrinski, 23.

${ }^{118}$ Evliyâ Çelebi, Evliyâ Çelebi, sv. V, 318; Evlija Čelebi, Putopis, 489.

${ }^{119}$ Petrić, Feletar, Feletar, Novi Zrin, 75; Kalšan, Međimurska povijest, 114; Kalšan, Nikola Zrinski, 20, 22.

${ }^{120}$ Evliyâ Çelebi, Evliyâ Çelebi, sv. VI, 318; Evlija Čelebi, Putopis, 491.

${ }^{121}$ Evliyâ Çelebi, Evliyâ Çelebi, sv. VI, 318; Evlija Čelebi, Putopis, 491.

${ }^{122}$ Evliyâ Çelebi, Evliyâ Çelebi, sv. VI, 321; Evlija Čelebi, Putopis, 496; Petrić, Feletar, Feletar, Novi Zrin, 85 .

${ }^{123}$ Evlijina poredba vezana je s doslovnim značenjem naziva za tip osmanskoga topa velikoga kalibra balyemez ("ne jede med”). Evlija Čelebi, Putopis, 496; Hans J. Kissling, "Balyemez", u: Encyclopaedia of Islam, ur. Hamilton A. R. Gibb et alia (Leiden: E. J. Brill, 1986), sv. I, 1007-1008.

${ }^{124}$ Evliyâ Çelebi, Evliyâ Çelebi, sv. VI, 321; Evlija Čelebi, Putopis, 496.

${ }^{125}$ Petrić, Feletar, Feletar, Novi Zrin, 83; Hausner, Négyesi, Padányi, “Novi Zrin”, 192.

${ }^{126}$ Evlija Čelebi, Putopis, 497; Evliyâ Çelebi, Evliyâ Çelebi, sv. VI, 321.

${ }^{127}$ Hausner, Négyesi, Padányi, “Novi Zrin”, 198, 205.
} 
nakon provale u utvrdu potisnuli branitelje prema obali Mure i drvenome mostu koji je vodio na drugu stranu. Uslijedila je borba prsa u prsa u kojoj su osmanski vojnici ubili velik broj protivnika pri i na mostu. ${ }^{128}$ Taj se opis slaže s kršćanskim izvorima koji također govore o borbama na mostu i pokolju branitelja. ${ }^{129}$

Evlija je opisao prostorni smještaj i izgled unutrašnjosti utvrde, koju je opisao kao "palanku s nasipom"130 odnosno drvenu utvrdu s opkopom ispunjenim vodom. Evlijin prikaz opsade u skladu je s pretežitim stavom u hrvatskoj historiografiji koji uveličava stratešku vrijednost i čvrstinu utvrde, ali Evlijina napomena o utvrdi kao palanci proturječi takvome stavu i zapravo se slaže sa suprotnim historiografskim stavom koji naglašava obrambene manjkavosti utvrde. Takvo su mišljenje imali i Montecuccoli i inženjer Jakob von Holst, habsburški predstavnici koji su proveli inspekciju utvrde. Montecuccoli je utvrdu opisao u vrlo negativnome tonu, također ju je nazvao palankom i spomenuo je jedino drvene zidove i opkop ispunjen vodom. ${ }^{131} \mathrm{~S}$ time su u skladu i stajališta mađarskih terenskih istraživača, koji su pronašli tragove drvene palanke bez zidanih bedema. ${ }^{132}$ U Evlijine tvrdnje nema razloga sumnjati jer njegovim "bombastičnim" opisima nije moglo ići u korist umanjivati velebnost utvrde.

Ni Montecuccoli ni Evlija ne navode da se na međimurskoj strani Mure preko puta utvrde nalazila ikakva utvrđena građevina, ${ }^{133}$ a mađarska terenska istraživanja jedino govore o mostobranu. ${ }^{134}$ Evlija je zapisao da je utvrda bila posve nova i da je sadržavala crkvicu, vojničke zgrade i zdenac na sredini tvrđavskoga dvorišta. ${ }^{135}$ $\mathrm{Na}$ Montecuccolijevu prikazu utvrde nalazi se jedanaest zgrada i nema zdenca koji spominje Evlija. ${ }^{136}$ Zdenac se, međutim, spominje u iskazu Pála Esterházyja, svjedoka bitke, u njegovu djelu Mars Hungaricus i bio je jedna od polaznih točaka u mađarskim terenskim istraživanjima. ${ }^{137}$ Evlija je zapisao: "Na vrhu drvene kupole ponad zdenca nalazio se pozlaćeni alem ${ }^{138}$ kao upozorenje svima. Kada $\underline{\text { su nevjernici tijekom proteklih zimskih dana zapalili utvrde Babócsa, Berzence }}$

\footnotetext{
${ }^{128}$ Evliyâ Çelebi, Evliyâ Çelebi, sv. VI, 322; Evlija Čelebi, Putopis, 497-498; Feletar, "Legradska kapetanija”, 74.

${ }^{129}$ Evliyâ Çelebi, Evliyâ Çelebi, sv. VI, 322; Evlija Čelebi, Putopis, 498; Petrić, Feletar, Feletar, Novi Zrin, 85.

${ }^{130}$ Evliyâ Çelebi, Evliyâ Çelebi, sv. VI, 323.

${ }^{131}$ Petrić, Feletar, Feletar, Novi Zrin, 78-79; Feletar, "Legradska kapetanija”, 68; Kalšan, Medimurska povijest, 107-108, 111; Kalšan, Nikola Zrinski, 18-19.

${ }^{132}$ Hausner, Négyesi, Padányi, “Novi Zrin”, 195.

${ }^{133}$ Kalšan, Međimurska povijest, 107-108, 111; Kalšan, Nikola Zrinski, 18-19.

${ }^{134}$ Hausner, Négyesi, Padányi, “Novi Zrin”, 196.

${ }^{135}$ Evliyâ Çelebi, Evliyâ Çelebi, sv. VI, 322-323; Evlija Čelebi, Putopis, 499; Feletar, "Legradska kapetanija”, 67.

${ }^{136}$ Kalšan, Nikola Zrinski, 19.

${ }^{137}$ Hausner, Négyesi, Padányi, “Novi Zrin”, 199-200.

${ }^{138}$ Islamski simbol u obliku polumjeseca s tri ili četiri kugle ispod njega, koji se nalazi na vrhu minareta kao ukras. Abdulah Škaljić, Turcizmi u srpskohrvatskom jeziku (Sarajevo: Svjetlost, 1966), 87.
} 
[Bobovec i Brežnica u jugozapadnoj Mađarskoj] i Pečuh, skinuli su alem s kupole utvrde Türbe [odnosno s turbeta, muslimanskoga mauzoleja] sultana Sulejmana [Veličanstvenog], koja se nalazi u blizini naše utvrde Siget na udaljenosti topovskog hica, i stavili su ga iznad toga bunara. Nakon pobjede veliki je vezir odmah skinuo taj alem s bunara i ponovo ga poslao u turbe sultana Sulejmana u blizini Sigeta, a [sandžak]begovima Mohača, Pečuha i Sigeta naredio je da poprave i obnove časno turbe i utvrdu." ${ }^{139}$ Kada Evlija govori o neprijateljevu ratnom pohodu iz "zimskih dana," sigurno govori o zimskome vojnom pohodu Nikole VII. u siječnju i veljači 1664. godine kada je kršćanska vojska spalila Berzence, Babócsu, utvrđeno mjesto Turbek u kojemu se nalazilo turbe sultana Sulejmana, Pečuh i slavni most kod Osijeka. ${ }^{140}$ Evlija spominje da su stanovnici podravskih sela pod vlašću Zrinskih sudjelovali u zimskome pohodu i njegov se opis posve slaže $s$ opisima pohoda u kršćanskim izvorima. ${ }^{141}$ Postrojbe Nikole VII. očito su tijekom pohoda uzele "suvenir" s turbeta sultana Sulejmana.

Veliki vezir Köprülü Fazıl Ahmed-paša i visoki osmanski dužnosnici nakon završetka opsade održali su vijećanje o sudbini Novoga Zrina, tvrdi Evlija. Dužnosnici su utvrdu nazvali "zjenicom oka" kršćanskih snaga i objektom koji osmanskoj državi "nanosi veliku štetu." Komentirali su da bi eventualno premještanje pola osmanske posade iz kaniške utvrde u obnovljeni Novi Zrin i njegovo pretvaranje u krajnju točku osmanske granice bilo beskorisno jer bi neprijatelj u slučaju osvajanja Kaniže nakon toga lako osvojio i Novi Zrin. Kada bi veliki vezir proglasio Novi Zrin sjedištem kaniškoga paše, pogriješio bi, tvrdili su dužnosnici, jer će na drugoj strani Mure neprijatelj sagraditi novu utvrdu i onda "u ovoj tvrđavi ne samo da neće moći hodati vojnici, nego ni guske ni kokoši," ${ }^{142}$ odnosno tvrđave će biti toliko blizu da će vojnici moći puškama gađati jedni druge, zapisao je Evlija. Zatim je opisao kako su visoki dužnosnici savjetovali velikome veziru da svu ratnu opremu pošalje u Kanižu i razori Novi Zrin, ${ }^{143}$ što su prema kršćanskim izvorima učinili 7. srpnja $1664 .{ }^{144}$

Zbog niza podudarnosti između Evlijina putopisa i neosmanskih izvora može se zaključiti da je Evlija doista posjetio Međimurje i Nikolu VII. Putopiščevi su podaci većinom vjerodostojni, ali neke dijelove opisa je preuveličao, na primjer

\footnotetext{
${ }^{139}$ Evliyâ Çelebi, Evliyâ Çelebi, sv. VI, 323; Evlija Čelebi, Putopis, 499.

${ }^{140}$ Joseph von Hammer-Purgstall, Historija Turskog (Osmanskog) Carstva (Zagreb: Nerkez Smailagić, 1979), sv. 2, 470; Ante Nazor, "Zimska vojna Nikole Zrinskoga”, u: Povijest obitelji Zrinski. Zbornik, ur. Zoran Ladić, Đuro Vidmarović (Zagreb: Matica hrvatska, 2007), 33; Petrić, Feletar, Feletar, Novi Zrin, 72.

${ }^{141}$ Evliyâ Çelebi, Evliyâ Çelebi, sv. VI, 318; Evlija Čelebi, Putopis, 491.

${ }^{142}$ Evliyâ Çelebi, Evliyâ Çelebi, sv. VI, 323; Evlija Čelebi, Putopis, 499. Za pomoć pri prevođenju ovoga dijela autografa Putopisa zahvalnost dugujem doc. dr. sc. Marti Andrić.

${ }^{143}$ Evliyâ Çelebi, Evliyâ Çelebi, sv. VI, 323; Evlija Čelebi, Putopis, 499; Petrić, Feletar, Feletar, Novi Zrin, $69,89$.

${ }^{144}$ Petrić, Feletar, Feletar, Novi Zrin, 85; Kalšan, Međimurska povijest, 114; Kalšan, Nikola Zrinski, 23.
} 
brojčane podatke, čime je vjerojatno podilazio ukusu ciljane čitalačke publike. Evlijini opisi Nikole VII., Čakovca, Legrada i Novoga Zrina zauzimaju važna mjesta u 5. i 6. dijelu Putopisa, a dijelovi koji se nalaze jedino u autografu upotpunjuju i djelomično razjašnjavaju navedene opise. Prikaz opsade Novoga Zrina vrlo je dojmljiv i u njega je putopisac unio svu svoju spisateljsku darovitost. Evlijini iskazi svjedoče nam o važnosti koju je obitelj Zrinski imala za povijest Hrvatske u 16. i 17. stoljeću iz osmanskoga kuta gledanja. Kroz Evlijine oči čini se da je "Veliki Zrinski” Nikola IV. u 16. stoljeću brojne stvari započeo, izgradio, utvrdio, dok je Nikola VII. na čelu "pokrajine Zrinskih" u 17. stoljeću bio neustrašivi ratnik prema kojemu putopisac osjeća strahopoštovanje, velikodušni vladar koji ide u lov u nepreglednim šumama koje posjeduje na turbulentnoj habsburško-osmanskoj granici i živo komunicira s bosanskim beglerbegom kao sebi ravnim. 


\section{Objavljeni izvori i literatura}

Anić, Vladimir. Rječnik hrvatskoga jezika. Zagreb: Novi Liber, 1998.

Dankoff, Robert. An Ottoman Mentality. The World of Evliya Çelebi. Leiden; Boston: Brill, 2006.

Dankoff, Robert. Evliya Çelebi Seyahatnamesi Okuma Sözlüğü. Istanbul: Türk Dilleri Araştırmaları Dizisi, 2004.

Evlija Čelebi. Putopis. Odlomci o jugoslovenskim zemljama, preveo Hazim Šabanović. Sarajevo: Svjetlost, 1967.

Evliyâ Çelebi bin Derviş Mehemmed Zillî. Evliyâ Çelebi Seyahatnâmesi Topkapı Sarayı Kütüphanesi Bağdat 307 Numaralı Yazmanın Transkripsiyonu - Dizini, priredili Yücel Dağlı, Seyit Ali Kahraman, İbrahim Sezgin, sv. V. Istanbul: Yapı Kredi Yayınları, 2001.

Evliyâ Çelebi bin Derviş Mehemmed Zillî. Evliyâ Çelebi Seyahatnâmesi Topkapı Sarayı Kütüphanesi Revan 1457 Numaralı Yazmanın Transkripsiyonu - Dizini. priredili Seyit Ali Kahraman, Yücel Dağlı, sv. VI, Istanbul: Yapı Kredi Yayınları, 2002.

Evliyâ Çelebi bin Derviş Mehemmed Zillî. Evliyâ Çelebi Seyahatnâmesi Topkapı Sarayı Kütüphanesi Bağdat 308 Numaralı Yazmanın Transkripsiyonu - Dizini. priredili Yücel Dağl1, Seyit Ali Kahraman, Robert Dankoff, sv. VII, Istanbul: Yap1 Kredi Yayınları, 2003

Feletar, Dragutin; Petrić, Hrvoje. "Die Festung Novi Zrin im Europäischen kontext (1661-1664)”. Podravina: časopis za multidisciplinarna istraživanja 1 (2002): 99-118.

Feletar, Dragutin. “Još nekaj o Legradskoj gori, s opisom lova iz 1660.” Dobravske novine 46 (2016): 22.

Feletar, Dragutin. "Legradska kapetanija u obrani od Osmanlija s posebnim osvrtom na Novi Zrin”. Rad Hrvatske akademije znanosti i umjetnosti. Razred za društvene znanosti 1 (2011): 47-81.

Feletar, Dragutin. “Značenje zrinskog Legrada i Novoga Zrina u obrani od Osmanlija”. U: Susreti dviju kultura. Obitelj Zrinski u hrvatskoj i mađarskoj povijesti, uredila Romana Horvat, 165-188. Zagreb: Matica hrvatska, 2012.

Feletar, Dragutin. “Zrinski Legrad i njegova uloga u obrani od Osmanlija”. U: Politička, kulturna i društvena djelatnost Zrinskih i Frankopana u Hrvatskoj, uredio Juraj Kolarić, 171-189. Čakovec: Zrinska garda Čakovec, 2011.

Hammer-Purgstall, Joseph von. Historija Turskog (Osmanskog) Carstva. Zagreb: Nerkez Smailagić, 1979.

Hausner, Gábor; Négyesi, Lajos; Padányi, József. "Novi Zrin u svjetlu izvora i istraživanja terena”. U: Susreti dviju kultura. Obitelj Zrinski u hrvatskoj i mađar- 
skoj povijesti, uredila Romana Horvat. 189-218. Zagreb: Matica hrvatska, 2012.

Horvat, Rudolf. "Zapljena Zrinskih imanja”. Hrvatsko kolo 4 (1908): 184-235.

Jurišić, Ivan. "Ostaci dobara Zrinskih nakon konfiskacije, prema popisu i procjeni 1672-1673., na primjeru utvrde Čakovec i popisa njenog inventara od 9. svibnja 1673." U: Povijest obitelji Zrinski. Zbornik, uredili Zoran Ladić, Đuro Vidmarović, 77-91. Zagreb: Matica hrvatska, 2007.

Kalšan, Vladimir. Međimurska povijest. Zagreb: Vladimir Kalšan, 2006.

Kalšan, Vladimir. Nikola Zrinski Čakovečki (1620.-1664.). Čakovec: Muzej Međimurja Čakovec, 2014.

Kissling, Hans J. "Balyemez". U: Encyclopaedia of Islam, uredili Hamilton A.R. Gibb et alia, sv. I, 1007-1008. Leiden: E. J. Brill, 1986.

Kovács, Iván Sándor. “Želučana materia”. U: Zrinski i Europa, uredila Jadranka Damjanov, 347-361. Zagreb: Društvo mađarskih znanstvenika i umjetnika u Hrvatskoj, 2000.

Kuntić-Makvić, Bruna, prev. "Šesto putno pismo Jakova Tolla Preplemenitome i presvijetlome gospodinu Nikoli Witsenu. Gradačko putovanje i gostoprimstvo Zrinskih". U: Zrinski i Europa, uredila Jadranka Damjanov, 151-159. Zagreb: Društvo mađarskih znanstvenika i umjetnika u Hrvatskoj, 2000.

Lopašić, Radoslav. “Spomenici Tržačkih Frankopana”. Starine 25 (1892): 201-332. Moačanin, Nenad; Jurin Starčević, Kornelija. “Novi' Evlija Čelebi: autograf 'Putopisa”'. Književna smotra 173 (2014): 77-90.

Moačanin, Nenad. "Pristup ekohistoriji Podravine prema osmanskim izvorima". Ekonomska i ekohistorija 1 (2005): 139-146.

Moačanin, Nenad. Turska Hrvatska. Hrvati pod vlašću Osmanskoga Carstva do 1791. Preispitivanja. Zagreb: Matica hrvatska, 1999.

Modrić, Rajka, ur. Povijesni spomenici obitelji Zrinskih i Frankopana $=$ Monumenta historica familiarum Zrinski et Frankopan, sv. 1: Popisi i procjena dobara (1672-1673) $=$ Conscriptiones et aestimationes bonorum (1672-1673). Zagreb: Jugoslavenska akademija znanosti i umjetnosti, 1974.

Nazor, Ante. "Zimska vojna Nikole Zrinskoga". U: Povijest obitelji Zrinski. Zbornik, uredili Zoran Ladić, Đuro Vidmarović, 21-42. Zagreb: Matica hrvatska, 2007.

Perči, Ljerka. "Vedute i planovi tvrđave Čakovec iz 17. stoljeća". Muzejski vjesnik. Glasilo muzeja sjeverozapadne Hrvatske 10 (1987): 49-52.

Petrić, Hrvoje. "Ljudi i selo Donja Dubrava na Dravi do sredine 20. stoljeća". U: Općina i župa Donja Dubrava: povijesno-geografska monografija, uredio Dragutin Feletar, 51-154. Samobor: Meridijani, 2007.

Petrić, Hrvoje; Feletar, Dragutin; Feletar, Petar. Novi Zrin. Zrinska utvrda na Muri (1661-1664). Donja Dubrava; Zagreb: Hrvatski zemljopis; Naklada dr. Feletar, 2001. 
Puntijar, Zlatko; Puntijar, Matea, ur. Kuharska knjiga Čakovečkog dvora Zrinskih u rukopisu i prijevodu iz vremena Nikole grofa Zrinskog - ban hrvatski 1647.-1664. Zagreb: V. O. Stari Puntijar, 2007.

Sekso, Ana, prev. "Széchyjev opis dvorca Zrinski prema starim spisima". U: Čakovec. Stari grad - Novi dvor. Povijesno-umjetnička studija, uredio Petar Puhmajer, 54-56. Zagreb: Hrvatski restauratorski zavod, služba za nepokretnu baštinu, 2006.

Šimčik, Antun. "Bilježnica sisačkoga špana Jurja Turjaka kanonika zagrebačkog iz g. 1649.” Vjesnik Kraljevskog državnog arkiva u Zagrebu 6 (1934): 36-49.

Škaljić, Abdulah. Turcizmi u srpskohrvatskom jeziku. Sarajevo: Svjetlost, 1966.

Tezcan, Nuran. "When did Evliya Çelebi die?". U: Evliyâ Çelebi. Studies and Essays Commemorating the 400th Anniversary of his Birth, uredili Nuran Tezcan, Semih Tezcan, Robert Dankoff, 30-32. Istanbul: Republic of Turkey, Ministry of Culture and Tourism Publications, 2012.

Uzunçarsılı, İsmail Hakkı. Osmanlı Tarihi III, sv. 2: XVİ. Yüzyıl Ortalarından XVİI. Yüzyıl Sonuna kadar. Ankara: Türk Tarih Kurumu, 1954.

Vujić, Žarka. "Baštinski svijet Nikole Zrinskog u Čakovcu”. U: Zrinski i Europa, uredila Jadranka Damjanov, 12-58. Zagreb: Društvo mađarskih znanstvenika i umjetnika u Hrvatskoj, 2000. 


\title{
The Zrinski Family in Evliya Çelebi's Travelogue: Parallels with the Neo-Ottoman Sources
}

\author{
Anđelko Vlašić \\ Croatian Institute of History \\ Department for the History of Slavonia, Baranja and Srijem \\ Ante Starčevića 8 \\ 35000 Slavonski Brod \\ Croatia \\ E-mail: andelko.vlasic@gmail.com
}

\section{Summary}

This article presents new insights concerning the history of the Zrinski family, based on the Travelogue of Ottoman explorer Evliya Çelebi. Croatian researchers of the Zrinski family have previously used this work in the translation of BosnianHerzegovinian orientalist Hazim Šabanović, but the recent edition of Evliya's autograph offers the possibility of comparison and allows for reaching new conclusions about the activity of Nicholas VII Zrinski in the period from 1660-1664, the way in which the Zrinski castle in Čakovac looked and operated, the situation in Medimurje concerning the warfare activities of Ottoman troops, the forested areas along the Habsburg-Ottoman border in what was then Slavonia, the siege of the fort of Novi Zrin in 1664, and generally the Ottoman-Croatian relations during the period in question. The newly acquired data have here been compared with the previously known sources and scholarly literature on the Zrinski family during the second half of the $17^{\text {th }}$ century, with new conclusions that take into account the Ottoman point of view as presented by Evliya Çelebi. A series of correspondences between his travelogue and other neo-Ottoman sources allow us to presume that he indeed visited Međimurje and Nicholas VII. His data are mostly accurate, although he exaggerated some parts of his description: thus, his overstated numbers were probably meant to cater for the tastes of his readership. Evliya's depiction of Nicholas VII, Čakovac, Legrad, and Novi Zrin take up an important part of Chapters 5 and 6 in the Travelogue and segments that are found only in the autograph complement and partly explain these descriptions. The siege of Novi Zrin is very impressively presented and reveals the writer's talents. Evliya's work is a crucial source for reaching conclusions about the importance of the Zrinski family in the history of Croatia during the $16^{\text {th }}$ and $17^{\text {th }}$ centuries, presented from the Ottoman point of view.

Keywords: Zrinski family, Evliya Çelebi, Međimurje, Slavonia, Novi Zrin, forests, Ottoman-Croatian relations 